\title{
HIPERTENSI, USIA, JENIS KELAMIN DAN KEJADIAN STROKE DI RUANG RAWAT INAP STROKE RSUD dr. M. YUNUS BENGKULU
}

\author{
Hypertension, Age, Sex, and Stroke Incidence In Stroke Installation Room \\ RSUD dr. M. Yunus Bengkulu
}

\author{
Dian Dwiana Maydinar ${ }^{1}$, S.Effendi ${ }^{2}$, Elin Sonalia ${ }^{1}$ \\ ${ }^{1}$ Progam Studi Keperawatan STIKES Tri Mandiri Sakti Bengkulu \\ ${ }^{2}$ Progam Studi Kesehatan Masyarakat STIKES Tri Mandiri Sakti Bengkulu \\ Email : dian_dwiananers@yahoo.co.id
}

\begin{abstract}
ABSTRAK
Stroke adalah gejala-gejala defisit fungsi susunan saraf yang diakibatkan oleh penyakit pembuluh darah otak dan bukan oleh yang lain dari itu. Penelitian ini bertujuan untuk mempelajari hubungan hipertensi, usia dan jenis kelamin dengan kejadian stroke di Ruang Rawat Inap Stroke RSUD dr. M. Yunus Bengkulu. Penelitian ini menggunakan desain cross sectional. Populasi dalam penelitian ini seluruh pasien yang mengalami stroke di Ruang Rawat Inap Stroke RSUD dr. M. Yunus Bengkulu pada tahun 2016 sebanyak 141 orang dengan stroke Hemoragik dan 173 orang dengan stroke non hemoragik dengan total 314 orang. Teknik pengambilan sampel adalah proporsional random sampling. Jumlah sampel sebanyak 34 orang dengan stroke hemoragik dan 42 orang yang stroke non hemoragik. Pengumpulan data dalam penelitian ini menggunakan data sekunder dengan melihat cacatan dokumentasi di Ruang Rawat Inap Stroke RSUDdr. M. Yunus Bengkulu. Teknik analisis data dilakukan dengan analisis univariat dan bivariat dengan menggunakan uji statistik Chi-Square $\left(\chi^{2}\right)$ melalui program SPSS. Hasil penelitian didapatkan : terdapat 42 orang $(55,3 \%)$ yang mengalami stroke non hemoragik, 47 orang $(61,8 \%)$ yang mengalami hipertensi, 40 orang (52,6\%) yang berusia $\geq 45$ tahun, 48 orang $(63,2 \%)$ yang berjenis kelamin laki-laki, ada hubungan antara hipertensi dengan kejadian stroke dengan kategori hubungan sedang $(R R=11,0)$, ada hubungan antara usia dengan kejadian stroke dengan kategori hubungan sedang $(R R=6,5)$, ada hubungan antara jenis kelamin dengan kejadian stroke dengan kategori hubungan sedang $(R R=5,0)$. Diharapkan kepada perawat agar dapat memberikan konseling kepada keluarga pasien stroke untuk rutin melakukan pemeriksaan kesehatan, sehingga dapat mengurangi komplikasi yang dapat ditimbulkan akibat stroke yang berkepanjangan
\end{abstract}

Kata Kunci : hipertensi, jenis kelamin, kejadian stroke, usia 


\section{ABSTRACT}

Stroke was a symptom of a deficit in the function of the nervous system caused by cerebrovascular disease and not by others. This study aimed to study the relationship between hypertension, age and sex with the incidence of stroke in the Inpatient Room Stroke RSUD dr. M. Yunus Bengkulu. This research used cross sectional design. The population in this study was all patients who had a stroke in the Inpatient Room Stroke RSUD dr. M. Yunus Bengkulu in 2016 as many as 141 people with Hemorrhagic stroke and 173 people with non hemorrhagic stroke with a total of 314 people. Sampling Technique was Proportional Random Sampling. The number of samples were 34 people with hemorrhagic stroke and 42 people who had non hemorrhagic stroke. The data collection in this study used secondary data by looking at documentary documentation in Inpatient Room of Stroke RSUD dr. M. Yunus Bengkulu. Data analysis technique was done by univariate and bivariate analysis used Chi-Square statistical test through SPSS program. The result of this study were: there were 42 people $(55,3 \%)$ who had non hemorrhagic stroke, 47 people $(61,8 \%)$ had hypertension, 40 people $(52,6 \%)$ aged $\geq 45$ years, 48 people $(63.2 \%)$ are male sex, there was a correlation between hypertension and stroke incidence in moderate category $(R R=11.0)$, there was a correlation between age and stroke with moderate category category $(R R=6.5)$, there was a relationship between sex with stroke incidence with moderate relationship category $(R R=5,0)$. It was expected that nurses should be able to provide counseling to families of stroke patients to routinely perform a medical examination, so as to reduce the complications that could be caused by a prolonged stroke.

Keywords : age, hypertension, sex, stroke

\section{A. Pendahuluan}

Stroke merupakan penyebab kematian ketiga di dunia setelah penyakit jantung koroner dan kanker baik di negara maju maupun negara berkembang. Satu dari 10 kematian disebabkan oleh stroke (Ennen,2004; Marsh \&Keyrounz,2010; American Heart Association,2014;Stroke Forum, 2015). Secara global, 15 juta orang terserang stroke setiap tahunnya, satu pertiga meninggal dan sisanya mengalami kecacatan permanen (Stroke Forum, 2015). Stroke merupakan penyebab utama kecacatan yang dapat di cegah (American Heart Association, 2014).

Organisasi Stroke Dunia mencatat hampir $85 \%$ orang yang mempunyai faktor resiko dapat terhindar dari stroke bila menyadari dan mengatasi faktor resiko tersebut sejak dini. Badan kesehatan dunia memprediksi bahwa kematian akibat stroke akan seiring dengan kematian akibat penyakit jantung dan kanker kurang lebih 6 juta pada tahun 2010 menjadi 8 juta di tahun 2030 (Yastroki,2012).

Di Amerika Serikat tercatat hampir setiap 45 detik terjadi kasus stroke, dan setiap 4 detik terjadi kematian akibat stroke. Pada suatu saat, 5,8 juta orang di Amerika Serikat mengalami stroke, yang mengakibatkan biaya kesehatan berkenaan dengan stroke mendekati 70 miliar dolar pertahun. (Medicastore, 2011).

Di Indonesia diperkirakan setiap tahun terjadi 500.000 penduduk terkena serangan stroke, sekitar 2,5\% 
atau 125.000 orang meninggal, dan sisanya cacat ringan maupun berat. Secara umum, dapat dikatakan angka kejadian stroke adalah 200 per 100.000 penduduk. dalam satu tahun, diantara per 100.000 penduduk, maka 200 orang akan menderita stroke (Yayasan Stroke Indonesia, 2012)

Stroke menurut World Health Organization (WHO) seperti yang dikutip Junaidin (2011) adalah suatu sindrom klinis dengan gejala berupa gangguan fungsi otak secara fokal maupun global, yang dapat menimbulkan kematian atau kecacatan yang menetap lebih dari 24 jam, tanpa penyebab lain kecuali gangguan vaskular.

Menurut Junaidi (2011) stroke merupakan penyakit gangguan fungsional otak akut fokal maupun global akibat terhambatnya aliran darah ke otak karena perdarahan (Stroke Hemoragik) atau sumbatan (Stroke Iskemik) dengan gejala dan tanda sesuai bagian otak yang terkena, yang dapat sembuh sempurna, sembuh dengan cacat, atau kematian.

Stroke iskemik merupakan suatu penyakit yang diawali dengan terjadinya serangkaian perubahan dalam otak yang terserang yang apabila tidak ditangani dengan segera berakhir kematian otak tersebut. Sedangkan stroke hemoragik merupakan penyakit gangguan fungsional otak akut fokal maupun global akibat terhambatnya aliran darah keotak yang disebabkan oleh perdarahan suatu arteri serebralis. Darah yang keluar dari pembuluh darah dapat masuk ke dalam jaringan otak, sehingga terjadi hematom.

Resiko terjadinya stroke meningkat seiring dengan berat dan banyaknya faktor resiko. Faktor resiko yang dapat dimodifikasi pada penyakit stroke diantaranya adalah riwayat stroke, hipertensi, penyakit jantung, diabetes melitus, penyakit karotis asimptomatis, transient ischemic attack, hiperkolestromia, penggunaan kontrasepsi oral, obesitas, merokok, alkholik, penggunaan narkotik, hiperhomosisteinemia, antibodi antifosfolipid, hiperurisemia, peninggian hematokrit, dan peningkatan kadar fibrinogen, sedangkan faktor resiko yang tidak dapat dimodifikasi yaitu umur, jenis kelamin, herediter, dan ras/ etnis (Misbach et al, 2004).

Riskesdas 2013 menunjukan, prevalensi hipertensi orang indonesia berusia lebih dari 18 tahun 25,8\%. Seseorang terkena hipertensi jika tekanan darah sistolik lebih tinggi dari $140 \mathrm{mmHg}$ dan tekanan darah diastolik lebih dari $90 \mathrm{mmHg}$. Tekanan sistolik menunjukan tekanan darah saat otot jantung berkontraksi dan tekanan diastolik saat otot jantung tak berkontraksi.

Salah satu faktor resiko yang penting untuk terjadinya stroke adalah Hipertensi untuk (Hariyono, 2002). Hasil penelitian Ramadhanis (2012) menyatakan bahwa pasien hipertensi mempunyai peluang sebesar $4,117 \mathrm{kali}$ menderita stroke dibandingkan pasien non hipertensi. Adanya faktor resiko stroke, membuktikan bahwa stroke adalah suatu penyakit yang dapat diramalkan sebelumnya dan bukan merupakan suatu hal yang terjadi begitu saja, sehingga istilah cerebrovascular accident telah ditinggalkan (Rambe, 2006).

Berdasarkan hasil penelitian yang dilakukan Juan et al (2010) seseorang yang mempunyai riwayat hipertensi 2 kali lebih beresiko terkena stroke. Berdasarkan hasil penelitian hipertensi meningkatkan resiko 3,8 kali terkena stroke (Sorganvi dkk, 2014).

Pada hipertensi yang definit, dengan tekanan darah sistolik $=140$ $\mathrm{mmHg}$ dan diastolik $=90 \mathrm{mmHg}$. Semakin bertambahnya umur, 
hipertensi merupakan salah satu faktor risiko terpenting yang dapat dimodifikasi untuk terjadinya serangan stroke. Pada penelitian ini, riwayat hipertensi, memberikan pengaruh yang bermakna untuk mengalami stroke dengan tingkat risiko 5,76 kali dibandingkan dengan yang tidak mempunyai riwayat hipertensi. Adanya hubungan antara riwayat hipertensi terhadap kejadian stroke sesuai dengan penelitian yang dilakukan oleh Leys, bahwa tekanan darah yang definit, dengan tekanan darah sistolik $=140$ dan diastolik $=90 \mathrm{mmHg}$ berhubungan dengan terjadinya serangan stroke. Hipertensi mendorong timbulnya stroke lewat diperberatnya atherosklerosis pada arkus aorta maupun arteri servikoserebral. Hipertensi lama akan menimbulkan lipohialinosis dan nekrosis firinoid yang memperlemah dinding pembuluh darah yang kemudian menyebabkan ruptur intima dan menimbulkan aneurisma.

Penelitian ini sesuai dengan penelitian yang dilakukan oleh Petrovitch, Marcuc, bahwa hipertensi terbukti mempuyai pengaruh terhadap kejadian stroke. Besarnya pengaruh tekanan darah, kemungkinan karena adanya perubahan terrjadi pada pembuluh darah serebral didalam jaringan otak. Perubahan ini menunjukkan faktor predisposisi stroke secara langsung, dan peningkatan proses atherogenesis merupakan faktor predisposisi perdarahan atau infark otak. Selain itu, hipertensi menyebabkan gangguan kemampuan autoregulasi pembuluh darah otak sehingga pada tekanan darah yang sama aliran darah ke otak pada penderita hipertensi sudah berkurang dibandingkan penderita normotensi. Makin lama hipertensi tidak diobati makin tinggi angka kejadian untuk stroke. (Sitorus et al, 2006).
Hipertensi merupakan faktor resiko utama terjadinya stroke. Sering disebut sebagai the silent killer karena hipertensi meningkatkan resiko terjadinya stroke sebanyak 6 kali. Dikatakan hipertensi bila tekanan darah lebih dari 140/ $90 \mathrm{mmHg}$. Semakin tinggi tekanan darah pasien kemungkinan stroke akan semakin basar, karena terjadinya kerusakan pada dinding pembuluh darah sehingga memudahkan terjadinya penyumbatan bahkan pecahnya pembuluh darah di otak.

Ekowati menambahkan, hipertensi bisa dicegah dengan mengurangi konsumsi makanan asin. Kebiasaan mengonsumsi makanan asin bisa meningkatkan resiko hipertensi 4,35 kali dibandingkan orang yang tak mengonsumsi makanan asin. Pengurangan konsumsi garam 2,9 gram per hari bisa menekan $50 \%$ orang yang perlu obat anti hipertensi, 22\% kematian akibat stroke, dan menurunkan $16 \%$ kematian akibat penyakit jantung koroner.

Di Asia sendiri khususnya Indonesia setiap tahun diperkirakan 500 ribu orang mengalami serangan stroke. Dari jumlah tersebut, sekitar $2,5 \%$ diantaranya meninggal dunia dan sisanya mengalami cacat ringan maupun berat. Masalah stroke semakin penting dan mendesak karena kini jumlah penderita stroke di Indonesia terbanyak menduduki urutan pertama di Asia. Jumlah pasien karena stroke menduduki urutan ke dua pada usia diatas 60 tahun dan urutan ke lima pada usia 15-59 tahun stroke merupakan penyebab kecacatan serius menetap nomor satu di seluruh dunia (Yastroki,2013)

Di Indonesia usia pasien stroke umunya berkisar pada usia 45 tahun keatas. Gaya hidup yang modern dan serba instan sepeti sekarang ini berpeluang besar bagi seseorang untuk 
terserang stroke di usia muda, baik laki-laki maupun usia produktif. Terdapat kira-kira 2 juta orang pertahun hidup dari stroke yang mempunyai beberapa kecacatan. Angka kejadian stroke adalah 200 per 100.000 penduduk dalam 1 tahun diantara 100.000 penduduk maka 800 orang akan menderita stroke. Persentase paien stroke adalah usia 35-44 tahun $0,2 \%$, usia $45-55$ tahun $0,7 \%$, usia $65-$ 74 tahun $2,7 \%$, usia $75-85$ tahun $10,4 \%$ (Pudiastuti,2011).

Laki- laki lebih cenderung untuk terkena stroke ebih tinggi dibadingkan perempuan, dengan perbandingan 1,3: 1, kecuali pada usia lanjut laki- laki dan perempuan hampir tidak berbeda. Laki- laki yangberumur 45 tahun bila bertahan hidup sampai 85 tahun kemungkinan terkena stroke $25 \%$, sedangkan resiko resiko bagi perempuan hanya $20 \%$. Pada laki- laki cenderung terkena stroke non hemoragik sedangkan perempuan lebih sering terkena perdarahan subarachnoid dan kematiannya 2 kali lebih tinggi dibandingkan laki- laki (Junaidi, 2011).

Umur dan jenis kelamin merupakan dua diantara faktor resiko stroke yang tidak dapat dimodifikasi. Stroke dapat menyerang semua umur, tetapi lebih sering dijumpai pada populasi usia tua. Setelah berumur 55 tahun, resikonya berlipat ganda setiap kurun waktu sepuluh tahun (Wiratmoko,2008). American Heart Association mengungkapkan bahwa serangan stroke lebih banyak terjadi pada laki-laki dibandingkan perempuan dibuktikan dengan hasil penelitian yang menunjukan bahwa prevalensi kejadian sroke lebih banyak pada lakilaki (Goldstein et al, 2006).

Penyakit stroke sering dianggap sebagai penyakit monopoli orang tua. Dulu, stroke hanya terjadi pada usia tua mulai 60 tahun, namun sekarang mulai usia 40 tahun seseorang sudah memiliki resiko stroke (Daurman, 2013).

Dalam penelitian yang dilakukan oleh Sofyan dkk dari seluruh subjek penderita stroke, proporsi terbanyak adalah kelompok umur $>55$ tahun $(67,5 \%)$ dan jenis kelamin terbanyak adalah laki- laki (51,9\%) namun tidak jauh berbeda dengan jenis kelamin perempuan $(48,1 \%)$. Dan berdasarkan status hipertensi, terbanyak adalah subjek dengan hipertensi $(53,1 \%)$.

$$
\text { Penelitian lain yang }
$$

berhubungan dengan penelitian ini adalah penelitian (Puspita dan Putro, 2008) yang mengatakan bahwa resiko terjadinya stroke pada kelompok umur $>55$ tahun adalah 3,640 kali dibandingkan kelompok umur $<55$ tahun. Stroke yang menyerang kelompok diatas usia 40 tahun adalah kelainan otak dan traumatik akibat proses patologi pada sistem pembuluh darah otak. (Farmacia,2009). Peningkatan frekuensi stroke seiring dengan peningkatan umur berhubungan dengan proses penuan, dimana semua organ tubuh mengalami kemunduran fungsi termasuk pembuluh darah otak. Pembuluh darah menjadi tidak elastis terutama bagian endotel yang mengalami penebalan pada bagian intima, sehingga mengakibatkan lumen pembuluh darah semakin sempit dan berdampak pada penurunan aliran darah otak (Kristiyawati et al, 2009).

Hasil penelitian sebelumnya yang dilakukan oleh Puspita dan Putro (2008). Yang mendapatkan bahwa jenis kelamin mempunyai hubungan yang bermakna dengan resiko kejadian stroke dengan resiko pada jenis kelamin laki- laki sebesar 4,375 kali dibandingkan dengan perempuan.

Jika serangan stroke terjadi berkali- kali, maka untuk sembuh dan bartahan hidup akan semakin kecil. Dengan mengetahui pengaruh 
hipertensi terhadap kejadian stroke iskemik dan stroke hemoragik, akan diharapkan dapat mencegah terjadinya stroke isemik maupun stroke hemoragik (Junaidi, 2011).

Rumusanmasalah dalam penelitian ini adalah "Apakah ada hubungan hipertensi, usia dan jenis kelamin dengan kejadian stroke di ruang rawat inap stroke RSUD dr. M. Yunus Bengkulu?.”. Tujuan penelitian ini adalah untuk untuk mengetahui hubungan hipertensi, usia dan jenis kelamin dengan kejadian stroke di ruang rawat inap stroke RSUD dr. M. Yunus Bengkulu.

\section{B. Metode Penelitian}

Lokasi penelitian ini dilakukan di RSUD dr. M. Yunus Bengkulu dan objek penelitian adalah seluruh pasien yang menderita Stroke di ruang rawat inap stroke RSUD dr. M. Yunus Bengkulu. Desain penelitian yang digunakan dalam penelitian ini adalah Cross Sectional. Populasi dalam penelitian ini adalah seluruh pasien yang mengalami stroke di ruang rawat inap stroke RSUD dr. M. Yunus Bengkulu pada tahun 2016 sebanyak 141 orang dengan stroke Hemoragik dan 173 orang dengan stroke non hemoragik dengan total 314 orang. Sampel diambil menggunakan teknik Proposional random sampling dan didapat sebanyak 42 orang sampel. Teknik Pengumpulan Data dalam penelitian ini adalah dengan menggunakan data sekunder. Teknik Analisis data menggunakan Analisis Univariat dan Analisis Bivariat, Analisis Bivariat bertujuan untuk menguji hubungan antara variabel independent (hipertensi, usia dan jenis kelamin) dengan variabel dependent (kejadian Stroke ). Uji statistik yang cocok yaitu uji statistik Chi-Square $\left(\chi^{2}\right)$ dengan tingkat kepercayaan 5,0\% dan alpha $(\alpha)$ 95\%. Selanjutnya untuk mengetahui keratan pengaruhnya digunakan uji Contingency Coeffisien $(C)$ dan untuk mengetahui faktor resiko digunakan Odd Ratio (OR).

\section{Hasil Penelitian \\ 1. Analisis Univariat}

Analisis univariatini bertujuan untuk melihat gambaran masingmasing variabel baikindependen (hipertensi, usia, jenis kelamin) dan dependen (kejadian stroke), adapun hasil analisis univariat adalah:

\section{Tabel 1}

Gambaran Kejadian Stroke pada Pasien yang Dirawat di Ruang Rawat Inap Stroke RSUD dr. M. Yunus Bengkulu

\begin{tabular}{cccc}
\hline No & Variabel & Frekuensi & Persentase (\%) \\
\hline 1 & Stroke Hemoragik & 34 & 44,7 \\
2 & Stroke Non Hemoragik & 42 & 55,3 \\
& Total & 76 & 100,0 \\
\hline
\end{tabular}

Berdasarkan Tabel 1 dapat hemoragik yaitu 42 orang $(55,3 \%)$ dan dilihat dari 76 pasien stroke terdapat sebagian lagi mengalami stroke sebagian besar mengalami stroke non hemoragik yaitu 34 orang $(44,7 \%)$. 
Tabel 2

Gambaran Hipertensi pada Pasien yang Dirawat di Ruang Rawat Inap Stroke RSUD dr. M. Yunus Bengkulu

\begin{tabular}{clccc}
\hline No & & Variabel & Frekuensi & Persentase (\%) \\
\hline 1 & Hipertensi & 47 & 61,8 \\
2 & Normal & Total & 76 & 38,2 \\
& & & & 100,0 \\
\hline
\end{tabular}

Berdasarkan Tabel 2 dapat yaitu 47orang (61,8\%) dan sebagian dilihat dari 76 pasien stroke terdapat lagi tekanan darahnya normal yaitu 29 sebagian besar mengalami hipertensi orang $(38,2 \%)$.

Tabel 3

Gambaran Usia pada Pasien yang Dirawat di Ruang Rawat Inap Stroke RSUD dr. M. Yunus Bengkulu

\begin{tabular}{cccc}
\hline No & Variabel & Frekuensi & Persentase $(\%)$ \\
\hline 1 & $\geq 45$ tahun & 40 & 52,6 \\
2 & $<45$ tahun & 36 & 47,4 \\
& Total & 76 & 100,0 \\
\hline
\end{tabular}

Berdasarkan Tabel 3 dapat tahunsebanyak 40 orang $(52,6 \%)$ dan dilihat dari 76 pasien stroke terdapat sebagian lagi berusia $<45$ tahun sebagian besar berusia $\geq 45$ sebanyak 36 orang $(47,4 \%)$.

Tabel 4

Gambaran Jenis Kelamin pada Pasien yang Dirawat di Ruang Rawat Inap Stroke RSUD dr. M. Yunus Bengkulu

\begin{tabular}{|c|c|c|c|}
\hline No & Variabel & Frekuensi & Persentase (\%) \\
\hline 1 & Laki-laki & 48 & 63,2 \\
\hline 2 & Perempuan & 28 & 36,8 \\
\hline & Total & 76 & 100,0 \\
\hline
\end{tabular}

Berdasarkan Tabel 4 dapat dilihat dari 76 pasien stroke terdapat sebagian besar berjenis kelamin lakilaki yaitu 48 orang $(63,2 \%)$ dan sebagian lagi berjenis kelamin perempuan yaitu 28 orang $(36,8 \%)$.

\section{Analisis Bivariat}

Analisis Bivariat dilakukan untuk mengetahui hubungan antara variabel independent ((hipertensi, usia, jenis kelamin) dan dependent (kejadian stroke), dilakukan dengan menggunakan uji chi-square $\left(\chi^{2}\right)$. 
Tabel 5

Hubungan Hipertensi dengan Kejadian Stroke pada Pasien yang Dirawat di Ruang Rawat Inap Stroke RSUD dr. M. Yunus Bengkulu

\begin{tabular}{|c|c|c|c|c|c|c|c|c|c|c|}
\hline \multirow{3}{*}{ Hipertensi } & \multicolumn{4}{|c|}{ Kejadian Stroke } & \multirow{2}{*}{\multicolumn{2}{|c|}{ Total }} & \multirow{3}{*}{$\chi^{2}$} & \multirow{3}{*}{$\mathrm{p}$} & \multirow{3}{*}{$\mathrm{C}$} & \multirow{3}{*}{ OR } \\
\hline & \multicolumn{2}{|c|}{ Hemoragik } & \multicolumn{2}{|c|}{$\begin{array}{c}\text { Non } \\
\text { Hemoragik }\end{array}$} & & & & & & \\
\hline & $\mathrm{F}$ & $\%$ & $\mathrm{~F}$ & $\%$ & $\mathrm{~F}$ & $\%$ & & & & \\
\hline Hipertensi & 30 & 88,24 & 17 & 40,47 & 47 & 61,85 & & & & \\
\hline Normal & 4 & 11,76 & 25 & 59,53 & 29 & 38,15 & 16,194 & 0,000 & 0,439 & 11,029 \\
\hline Total & 34 & 100,0 & 42 & 100,0 & 76 & 100,0 & & & & \\
\hline
\end{tabular}

Berdasarkan Tabel 5 di atas antara hipertensi dengan kejadian stroke. Tampak dari 34 orang yang mengalami stroke hemoragik terdapat 30 orang mengalami hipertensi dan 4 orang tekanan darahnya normal. Dari 42 orang yang mengalami stroke non hemoragik terdapat 17orang mengalami hipertensi dan 25 orang tekanan darahnya normal.

Hasil uji statistik Chi-Square (continuity correction) didapatkan nilai $x^{2}=16,194$ dengan $\mathrm{p}=0,000<0,05$ berarti signifikan, maka Ho ditolak Ha diterima. Jadi terdapat hubungan yang signifikan antara hipertensi dengan kejadian stroke pada pasien yang dirawat di ruang rawat inap stroke RSUD dr. M. Yunus Bengkulu.

Hasil uji contingency coefficient didapat nilai $\mathrm{C}=0,439$ dengan $\mathrm{P}=0,000<0,05$ berarti signifikan. Nilai $\mathrm{C}=0,439$ tersebut dibandingkan dengan nilai $\mathrm{C}_{\max }$. Karena nilai $\mathrm{C}$ tidak jauh dengan nilai $\mathrm{C}_{\max }=0,707$ maka katagori hubungannya adalah sedang. Hasil uji Risk Estimate didapat nilai OR $=11,029$ yang artinya pasien stroke dengan hipertensi beresiko11 kali lipat mengalami stroke hemoragikjika dibandingkan dengan pasien stroke yang tekanan darahnya normal.

Tabel 6

Hubungan Usia dengan Kejadian Stroke pada Pasien yang Dirawat di Ruang Rawat Inap Stroke RSUD dr. M. Yunus Bengkulu

\begin{tabular}{|c|c|c|c|c|c|c|c|c|c|c|}
\hline \multirow{3}{*}{ Usia } & \multicolumn{4}{|c|}{ Kejadian Stroke } & \multirow{2}{*}{\multicolumn{2}{|c|}{ Total }} & \multirow{3}{*}{$\chi^{2}$} & \multirow{3}{*}{$\mathrm{P}$} & \multirow{3}{*}{$\mathrm{C}$} & \multirow{3}{*}{ OR } \\
\hline & \multicolumn{2}{|c|}{ Hemoragik } & \multicolumn{2}{|c|}{$\begin{array}{c}\text { Non } \\
\text { Hemoragik }\end{array}$} & & & & & & \\
\hline & $\mathrm{F}$ & $\%$ & $\mathrm{~F}$ & $\%$ & $\mathrm{~F}$ & $\%$ & & & & \\
\hline$\geq 45$ tahun & 26 & 76,47 & 14 & 33,33 & 40 & 52,63 & & & & \\
\hline$<45$ tahun & 8 & 23,53 & 28 & 66,67 & 36 & 47,37 & 12,347 & 0,000 & 0,395 & 6.500 \\
\hline Total & 34 & 100,0 & 42 & 100,0 & 76 & 100,0 & & & & \\
\hline
\end{tabular}

Berdasarkan Tabel 6 di atas antara usia dengan kejadian stroke. Tampak dari 34 orang yang mengalami stroke hemoragik terdapat 26 orang yang berusia $\geq 45$ tahun dan 8 orang yang berusia $<45$ tahun. Dari 42 orang yang mengalami stroke non hemoragik terdapat 14 orang yang berusia $\geq 45$ tahun dan 28 orang yang berusia $<45$ tahun

Hasil uji statistik Chi-Square (continuity correction) didapatkan nilai $x^{2}=12,347$ dengan $\mathrm{p}=0,000<0,05$ berarti signifikan, maka Ho ditolak Ha diterima. Jadi terdapat hubungan yang signifikan antara usia dengan kejadian 
stroke pada pasien yang dirawat di ruang rawat inap stroke RSUD dr. M. Yunus Bengkulu. Hasil uji contingency coefficient didapat nilai $\mathrm{C}=0,395$ dengan $\mathrm{p}=0,000<0,05$ berarti signifikan. Nilai $\mathrm{C}=0,395$ tersebut dibandingkan dengan nilai $\mathrm{C}_{\max }$. Karena nilai $\mathrm{C}$ tidak jauh dengan nilai
$\mathrm{C}_{\max }=0,707 \quad$ maka katagori hubungannya adalah sedang. Hasil Uji Risk Estimate didapat nilai OR $=6,500$ yang artinya pasien stroke yang berusia $\geq 45$ tahun beresiko 6,5 kali lipat mengalami stroke hemoragik jika dibandingkan dengan pasien stroke yang yang berusia $<45$.

Tabel 7

Hubungan Jenis Kelamin dengan Kejadian Stroke pada Pasien yang Dirawat di Ruang Rawat Inap Stroke RSUD dr. M. Yunus Bengkulu

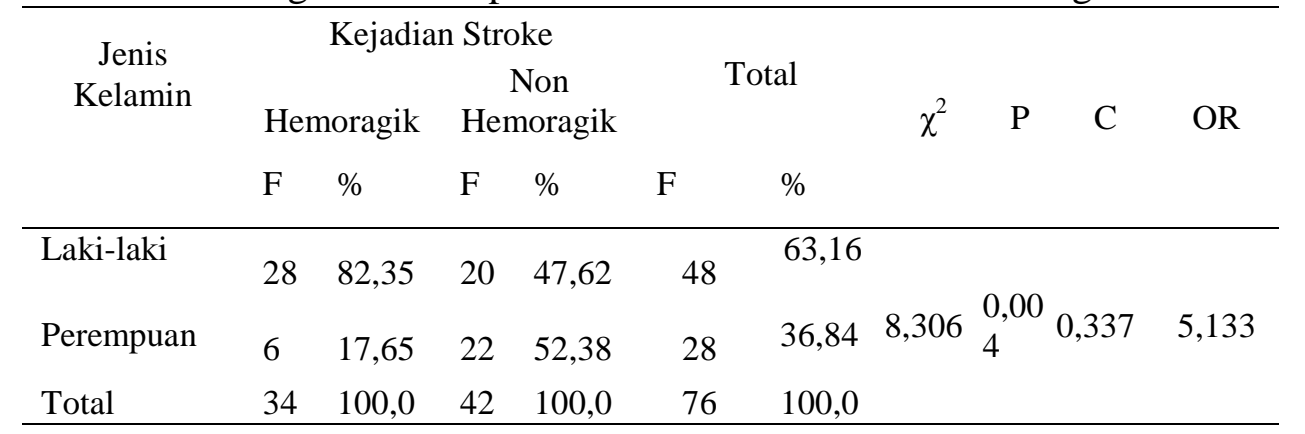

Berdasarkan Tabel 7 di atas antara jenis kelamin dengan kejadian stroke. Tampak dari 34 orang yang mengalami stroke hemoragik terdapat 28 orang yang berjenis kelamin lakilaki dan 6 orang perempuan. Dari 42 orang yang mengalami stroke non hemoragik terdapat 20 orang yang berjenis kelamin laki-laki dan 22 orang perempuan.

Hasil uji statistik Chi-Square (continuity correction) didapatkan nilai $x^{2}=8,306$ dengan $\mathrm{p}=0,004<0,05$ berarti signifikan, maka Ho ditolak $\mathrm{Ha}$ diterima. Jadi terdapat hubungan yang signifikan antara jenis kelamin dengan kejadian stroke pada pasien yang dirawat di ruang rawat inap stroke RSUD dr. M. Yunus Bengkulu.

Hasil uji contingency coefficient didapat nilai $\mathrm{C}=0,337$ dengan $\mathrm{P}=0,002<0,05$ berarti signifikan. Nilai $\mathrm{C}=0,337$ tersebut dibandingkan dengan nilai $C_{\max }$. Karena nilai $C$ tidak jauh dengan nilai $\mathrm{C}_{\max }=0,707$ maka katagorihubungannya adalah sedang.
Hasil Uji Risk Estimate didapat nilai $\mathrm{OR}=5,133$ yang artinya pasien stroke yang berjenis kelamin laki-laki lebih beresiko 5 kali lipat mengalami stroke hemoragik jika dibandingkan dengan pasien perempuan.

\section{Pembahasan}

Berdasarkan hasil tabulasi silang antara hipertensi dengan kejadian stroke. Tampak dari 34 orang yang mengalami stroke hemoragik terdapat 30 orang mengalami hipertensi dan 4 orang tekanan darahnya normal. Ini karena pembuluh darah pada orang dengan hipertensi terutama yang sudah kronis akan mempengaruhi elastisitas dinding pembuluh darahnya dan akan membuat pembuluh darah rentan robek, serta meningkatkan resiko terbawanya gumpalan-gumpalan lemak dalam pembuluh darah yang kecil di otak sehingga dapat menyumbat aliran darah bahkan dapat memecahkan pembuluh darah di otak yang mengakibatkan terjadinya stroke hemoragik. Walaupun ada juga 
beberapa kasus stroke hemoragik yang pada saat pemeriksaan terdapat 4 orang (Tn.A, Tn.M, Ny.S, Tn.T) yang tekanan darahnya normal, ini dapat disebabkan karena pasien sudah mendapatkan penanganan untuk menurunkan tekanan darahnya sehingga menjadi normal.

Dari 42orang yang mengalami stroke non hemoragik terdapat 17 orang mengalami hipertensi dan 25 orang tekanan darahnya normal. Dari data diatas menunjukkan bayak pasien stroke non hemoragik yaitu 17 orang dengan hipertensi yang terdiri dari 11 orang dengan hipertensi sedang (TD sistol 160-179 dan diastole 100-109 $\mathrm{mmHg}$ ) dan 6 orang kategori hipertensi ringan (TD sistol 140-159 dan diastole 90-99 $\mathrm{mmHg}$ ), Kondisi tekanan darah inijuga dapat mengganggu aliran darah tubuh walaupun tidak separah yang di timbulkan pada hipertensi yang sudah berat. Sehingga kondisi hipertensi ringan sampai sedang ini dapat mempengaruhi diameter pembuluh darah yang semakin lama mengecil sehingga darah yang mengalir ke otak pun akan berkurang, dengan pengurangan aliran darah otak. Maka otak akan kekurangan suplai oksigen dan glukosa sehingga jaringan otak lama-lama akan mati berakibat pada terjadinya stroke non hemoragik. Walaupun ada juga 25 orang yang tekanan darahnya normal tetapi mengalami stroke non hemoragik ini karena serangan stroke baru terjadi pasien dan langsung ditangani oleh tim kesehatan, sehingga tekanan darahnya masih dapat menurun atau normal.

Penelitian ini sejalan dengan pendapat Junaidi (2011), hipertensi merupakan faktor resiko utama terjadinya stroke. Sering disebut sebagai the silent killer karena hipertensi meningkatkan resiko terjadinya stroke sebanyak 6 kali. Dikatakan hipertensi bila tekanan darah lebih dari 140/ $90 \mathrm{mmHg}$. Semakin tinggi tekanan darah pasien kemungkinan stroke akan semakin basar, karena terjadinya kerusakan pada dinding pembuluh darah sehingga memudahkan terjadinya penyumbatan bahkan pecahnya pembuluh darah di otak.

Hasil uji statistik Chi-sguare (continuity correction) didapatkan adanya hubungan yang signifikan antara hipertensi dengan kejadian stroke pada pasien yang dirawat di ruang rawat inap stroke RSUD dr. M. Yunus Bengkulu. ini sejalan teori Hariyono (2002), yang menyatakan bahwa Salah satu faktor resiko yang penting untuk terjadinya stroke adalah Hipertensi yang mampu mengganggu fungsi kerja jantung dan aliran darah, sehingga resiko terjadinya stroke lebih besar pada orang hipertensi.

Hasil uji contingency coefficienthubungan hipertensi dengan kejadian stroke pada pasien yang dirawat di ruang rawat inap stroke RSUD dr. M. Yunus Bengkulu dalam katagorihubungannya sedang. Ini karena banyak faktor lain yang dapat menyebabkan stroke selain hipertensi seperti penyakit diabetes melitus, usia, jenis kelamin, kebiasaan pola hidup tidak sehat. Penelitian ini sejalan dengan pendapat Yastroki (2012), hipertensi dapat menimbulkan perubahan patologik yang berbeda pada pembuluh darah sedang dan pembuluh darah kecil otak.Berdasarkan ini stroke yang timbul akibat hipertensi dapat dibedakan atas dua golongan yang gambaran patologi dan kliniknya berbeda. Perubahan patologiknya adalah berupa aterosklerosis. Di sini peranan hipertensi hanyalah sebagai salah satu faktor risiko disamping faktor-faktor lain seperti diabetes mellitus, hiperlipidemia, merokok dan lain-lain. 
Hasil uji Risk Estimate didapatkan bahwa pasien stroke dengan hipertensi beresiko 11 kali lipat mengalami stroke hemoragik jika dibandingkan dengan pasien stroke yang tekanan darahnya normal. Ini sejalan dengan hasil penelitian Juan (2010), seseorang yang mempunyai riwayat hipertensi 2 kali lebih beresiko terkena stroke. Berdasarkan hasil penelitian hipertensi meningkatkan resiko 3,8 kali terkena stroke.

Didukung pula oleh pendapat Ramadhanis (2012), menyatakan bahwa pasien hipertensi mempunyai peluang sebesar 4,117 kali menderita stroke dibandingkan pasien non hipertensi. Adanya faktor resiko stroke, membuktikan bahwa stroke adalah suatu penyakit yang dapat diramalkan sebelumnya dan bukan merupakan suatu hal yang terjadi begitu saja.

Berdasarkan hasil tabulasi silang antara usia dengan kejadian stroke. Tampak dari 34 orang yang mengalami stroke hemoragik terdapat 26orang yang berusia $\geq 45$ tahun dan 8 orang yang berusia $<45$ tahun. Sedangkan dari 42orang yang mengalami stroke non hemoragik terdapat 14 orang yang berusia $\geq 45$ tahun dan 28 orang yang berusia $<45$ tahun.

Dari hasil penelitian diatas dapat dilihat kejadian stroke hemoragik dan non hemoragik banyak terjadi pada usia $\geq 45$ tahun, ini karena pada usia ini kondisi system organ tubuhnya mulai menurun terutama elestisitas pembuluh darahnya yang mulai menurun apalagi bila pasien disertai dengan beberapa penyakit penyerta seperti hipertensi, jantung, diabetes, atau adanya faktor genetik dari orag tua yang pernah mengalami stroke. Kondisi-kondisi ini akan mempercepat terjadinya gangguan pada aliran darah ke otak yang lamakelamaan bila penanganannya tidak tepat akan mengakibatkan pecahnya pembuluh darah di otak.

Selain itu ada juga kasus stroke hemoragik yaitu 8 orang (Tn.G, Tn.C, Ny.Li, Ny.Ky, Tn.P, Tn.J, Tn.D, Ny.Ru) pada usia mudah yaitu <45 tahun, yang terdiri dari 5 orang yang merupakan perokok berat dan pecandu kafeein (kopi), sedangkan yang 3 orang memiliki riwayat pengkonsumsi alkohol yang hampir setiap malam. Ini sangat bisa terjadi apabila memang sejak dini menjalani gaya hidup yang tidak sehat, maka dari itu dampaknya bisa sangar cepat atau langsung dirasakan.

Hasil penelitian ini sejalan dengan pendapat Kristiyawati (2009), peningkatan frekuensi stroke seiring dengan peningkatan umur berhubungan dengan proses penuan, dimana semua organ tubuh mengalami kemunduran fungsi termasuk pembuluh darah otak. Pembuluh darah menjadi tidak elastis terutama bagian endotel yang mengalami penebalan pada intima, dan berkibatkan penurunan aliran darah otak.

Serta didukung oleh pendapat Sylvia (2005), kerentanan terhadap aterosklerosis koroner meningkat seiring bertambahnya usia. Namun demikian jarang timbul penyakit serius sebelum usia 40 tahun. Peningkatan usia berkaitan proses pengendapan lemak pada dinding pembuluh darah, yang mengalami penyempitan seiring berjalannya umur serta proses kerapuhan dinding pembuluh semakin panjang sehingga semakin tua usia seseorang maka semakin besar kemungkinan terserang penyakit stroke.

Hasil uji statistik Chi-square (continuity correction) didapatkan adanya hubungan yang signifikan antara usia dengan kejadian stroke pada pasien yang dirawat di ruang rawat inap stroke RSUD dr. M. Yunus 
Bengkulu ini sejalan dengan teori Wiratmoko (2008), umur dan jenis kelamin merupakan dua diantara faktor resiko stroke yang tidak dapat dimodifikasi. Stroke dapat menyerang semua umur, tetapi lebih sering dijumpai pada populasi usia tua. Setelah berumur 55 tahun, resikonya berlipat ganda setiap kurun waktu sepuluh tahun

Hasil uji contingency coefficient hubungan usia dengan kejadian stroke pada pasien yang dirawat di ruang rawat inap stroke RSUD dr. M. Yunus Bengkulu katagori hubungannya sedang. Ini karena usia bukan satusatunya faktor utama terjadi stroke, tetapi masih banyak faktor lain seperti penyakit bawaan hipertensi, DM, jantung, pola hidup tidak sehat, merokok, alkohol, obesitas, serta jenis kelamin. Ini sejalan dengan pendapat Daurman (2013), Penyakit stroke sering dianggap sebagai penyakit monopoli orang tua. Dulu, stroke hanya terjadi pada usia tua mulai 60 tahun, namun sekarang mulai usia 40 tahun seseorang sudah memiliki resiko stroke, namun penyakit ini juga dapat disebabkan oleh banyak faktor resiko seeprti orang obesitas, perokok, peminum, dan yang memiliki penyakit diabetes atau hipertensi.

Hasil uji Risk Estimate didapatkan bahwa pasien stroke yang berusia $\geq 45$ tahun beresiko6,5 kali lipat mengalami stroke hemoragik jika dibandingkan dengan pasien stroke yang yang berusia <45.Ini sejalan dengan pendapat penelitian Puspita dan Putro, (2008) yang mengatakan bahwa resiko terjadinya stroke pada kelompok umur > 55 tahun adalah 3,640 kali dibandingkan kelompok umur < 55 tahun. Stroke yang menyerang kelompok diatas usia 40 tahun adalah kelainan otak dan traumatik akibat proses patologi pada sistem pembuluh darah otak.
Berdasarkan hasil tabulasi silang antara jenis kelamin dengan kejadian stroke.Tampak dari 34orang yang mengalami stroke hemoragik terdapat 28 orang yang berjenis kelamin laki-laki dan 6 orang perempuan. Dari 42 orang yang mengalami stroke non hemoragik terdapat 20 orang yang berjenis kelamin laki-laki dan 22 orang perempuan.

Dari hasil penelitian diatas dapat dilihat bahwa angka kejadian stroke hemoragik pada 28 orang lakilaki yang terdiri dari 19 orang perokok berat dan pencandu kafeein, 5 orang pengkonsumsi minuman beralkohol, dan 4 orang suka mengkonsumsi makanan siap saji dan berlemak serta jarang olahraga. Sedangkan 20 orang laki-laki yang mengalami stroke non haemoragik ini juga memiliki kebiasaan buruk yang hampir sama dengan pasien yang mengalami stroke haemoragik tetapi belum terlalu lama. Sehingga kondisi ini mampu meningkatkan penumpukan lemak didalam pembuluh darah yang lamakelamaan akan mengganggu aliran darah ke otak dan beresiko menyebabkan pecahnya pembuluh darah di otak. Sedangkan stroke yang terjadi pada perempuan ini banyak terjadi pada wanita usia lanjut atau menopause, karena setelah menopause system hormon estrogen tidak berfungsi lagi untuk memperbaruhi system peredaran darah dalam tubuh dan kondisi system imun tubuhnya pun mulai menurun. Sehingga penumpukan lemak dalam darah pun mampu mempengaruhi terjadinya penyumbatan di otak.

Penelitian ini didukung oleh pendapat Menurut Sylvia (2005), secara keseluruhan, resiko aterosklerosis koroner lebih besar pada laki-laki daripada perempuan. Perempuan relatif kebal terhadap 
penyakit ini sampai usia menopause. Efek perlindungan estrogen adanya imunitas wanita pada usia sebelum menopause. Serta didukung oleh pendapat Watila(2010), kejadian stroke terjadi pada laki- laki karena pada lakilaki terdapat hormon testosteron, dimana hormon ini dapat meningkatkan kadar LDL, apabila kadar LDL tinggi maka dapat meningkatkan kadar kolesterol dalam darah yang merupakan faktor resiko terjadinya penyakit degeneratif seperti stroke.

Hasil uji statistik Chi-sguare (continuity correction) didapatkan adanya hubungan yang signifikan antara jenis kelamin dengan kejadian stroke pada pasien yang dirawat di ruang rawat inap stroke RSUD dr. M. Yunus Bengkulu. Hal ini sejalan dengan pendapat Goldstein (2006), American Heart Association mengungkapkan bahwa serangan stroke lebih banyak terjadi pada lakilaki dibandingkan perempuan dibuktikan dengan hasil penelitian yang menunjukan bahwa prevalensi kejadian sroke lebih banyak pada lakilaki.

Hasil uji contingency coefficienthubungan jenis kelamin dengan kejadian stroke pada pasien yang dirawat di ruang rawat inap stroke RSUD dr. M. Yunus Bengkulu dalam katagorihubungannya sedang. Ini karena jenis kelamin bukan satusatunya penyebab terjadinya stroke, tetapi masih banyak penyebab lain seperti usia, gaya hidup, genetic, obesitas, dan penyakit bawaan seperti hipertensi, diabetes, dan jantung.

Ini sejalan dengan pendapat Mutmainah (2012), Laki- laki memiliki kecenderungan lebih besar terkena stroke pada usia dewasa dibandingkan dengan perempuan dengan perbandingan 2:1. Walaupun laki- laki lebih rentan terkena penyakit stroke dari pada perempuan pada usia yang lebih muda, tetapi perempuan akan menyusul pada usia mereka mencapai monopouse karena terjadi penurunan hormon estrogen yang berperan melindungi perempuan samapai mereka melewati masa- masa melahirkan anak. Selain itu, pada usia dewasa awal (18-40 tahun) laki- laki memiliki resiko terkena stroke iskemik atau perdarahan intra serebral lebih tinggi $20 \%$ dari pada perempuan. Namun, perempuan usia berapapun memiliki resiko perdarahan subaracnoid sekitar 50\% lebih besar. Sehingga baik jenis kelamin laki- laki maupun perempuan memiliki peluang yang sama untuk terkena stroke pada usia dewasa awal (18-40 tahun).

Hasil uji Risk Estimate didapatkan bahwa pasien stroke yang berjenis kelamin laki-laki lebih beresiko5 kali lipat mengalami stroke hemoragikjika dibandingkan dengan pasien perempuan.Ini sejalan dengan hasil penelitian Puspita \& Putro (2008), yang menyatakan bahwa jenis kelamin mempunyai hubungan yang bermakna dengan resiko kejadian stroke dengan resiko pada jenis kelamin laki- laki sebesar 4,375 kali dibandingkan dengan perempuan.

Dari hasil penelitian yang dilakukan peneliti dapat dilihat bahwa kejadian stroke haemoragik dan non haemoragik paling banyak terjadi pada pasien-pasien dengan hipertensi, usia lanjut atau $\geq 45$ tahun, serta banyak terjadi pada laki-laki. Kondisi ini menunjukkan bahwa perlu adanya perhatian khusus dari pihak keluarga maupun tim kesehatan dalam upaya pencegahan kasus stroke yang sangat berbahaya bagi kelangsungan hidup seseorang dengan cara memberikan perhatian lebih pada anggota keluarga yang beresiko tinggi terutama dari segi makanan yang di konsumsinya untuk mengurangi makanan-makanan yang 
mengandung banyak lemak serta selalu melakukan pemeriksaan kesehatan untuk pencegahan komplikasi lebih lanjut, sedangkan tim kesehatan diharapkan dapat melakukan tindakan pencegahan dengan memberikan penyuluhan kesehatan tentang pola hidup sehat, dan pengolahan makananmakanan yang baik bagi orang yang beresiko stroke dengan cara mendemontrasikan secara langsung maupun melakukan pembagian famplet kepada masyarakat. Sehingga diharapkan dengan pencegahan ini akan mengurangi resiko terjadi stroke dalam keluarga.

\section{E. Kesimpulan}

1. Dari 76 , terdapat 42 orang $(55,3 \%)$ yang mengalami stroke non hemoragik di ruang rawat inap stroke RSUD dr. M. Yunus Bengkulu.

2. Dari 76 responden, terdapat 47 orang $(61,8 \%)$ yang mengalami hipertensi di ruang rawat inap stroke RSUD dr. M. Yunus Bengkulu.

3. Dari 76 responden, terdapat 40 orang $(52,6 \%)$ yang berusia $\geq 45$ tahun di ruang rawat inap stroke RSUD dr. M. Yunus Bengkulu.

4. Dari 76 responden, terdapat 48 orang $(63,2 \%)$ yang berjenis kelamin laki-laki di ruang rawat inap stroke RSUD dr. M. Yunus Bengkulu.

5. Ada hubungan yang signifikan antara hipertensi dengan kejadian stroke pada pasien yang dirawat di ruang rawat inap stroke RSUD Dr. M. Yunus Bengkulu dengan kategori hubungan sedang karena Ada faktor lain yang mempengaruhi, seperti penyakit jantung, diabetes, perokok dan alkohol

6. Ada hubungan yang signifikan antara usia dengan kejadian stroke pada pasien yang dirawat di ruang rawat inap stroke RSUD
M. Yunus Bengkulud engan kategori hubungan sedang.

7. Ada hubungan yang signifikan antara jenis kelamin dengan kejadian stroke pada pasien yang dirawat di ruang rawat inap stroke RSUD dr. M. Yunus Bengkulu dengan kategori hubungan sedang.

\section{Daftar Pustaka}

Junaidi. (2011). Stroke, Waspadai Ancamannya. Yogyakarta: Penerbit Andi.

Misbach. J., et al. (2004). Kelompok Studi Serebrovaskuler

Perhimpunan Dokter Spesialis Saraf Indonesia. Jakarta: Departemen Kesehatan Republik Indonesia.

Puspita, M. aan Putro, G. (2008). Hubungan Gaya Hidup Terhadap Kejadian Stroke di Rumah Sakit Umum Daerah Gambiran Kediri. Buletin Penelitian Sistem Kesehatan, Volume 11 (3), hal 263-269.

Rambe. (2006). Hubungan Umur, Jenis Kelamin, dan Hipertensi dengan Kejadian Stroke di RSU Provinsi Tenggara Tahun 2012. Jurnal Kesehatan. Diakses pada tanggal 25 februari 2017, pukul 09.30 Wib.

Sitorus, R.J., et al. 2006. FaktorFaktor Resiko yang Mempengaruhi Kejadian Stroke pada Usia Muda Kurang dari 40 Tahun.RS. Semarang.

Yastroki. 2012. Diakses dari http://Yastroki.com.

Yayasan Stroke Indonesia.2012. Angka Kejadian Stroke Meningkat

Tajam.http://php7id.317 diakses 25 februari 2017. 